\title{
Indigenous Bacillus spp. ability to growth promoting activities and control bacterial wilt disease (Ralstonia solanacearum)
}

\author{
YULMIRA YANTI ${ }^{1, \vartheta}$, TRIMURTI HABAZAR ${ }^{1}$, REFLINALDON $^{1}$, CHAINUR RAHMAN NASUTION ${ }^{1}$, \\ SRIMANO FELIA ${ }^{2}$ \\ ${ }^{1}$ Department of Plant Protection, Faculty of Agriculture, Universitas Andalas. Jl. Unand, Limau Manih, Padang 25163, West Sumatra, Indonesia. Tel. \\ +62-751-72773, Fax.: +62-751-72702, `email: yy.anthie79@gmail.com \\ ${ }^{2}$ Department of Agroecotechnology, Faculty of Agriculture, Universitas Andalas. Jl. Unand, Limau Manih, Padang 25163, West Sumatra, Indonesia
}

Manuscript received: 23 January 2017. Revision accepted: 6 October 2017.

\begin{abstract}
Yanti Y, Habazar T, Reflinaldon, Nasution CR, Felia S. 2017. Indigenous Bacillus spp. ability to growth promoting activities and control bacterial wilt disease (Ralstonia solanacearum). Biodiversitas 18: 1562-1567. Among the species of Plant Growth Promoting Rhizobacteria, Bacillus spp. has been found to provide beneficial effects to different plant species. Based on our previous research from in planta screening's method, we found six indigenous strains of Bacillus spp., which had the ability to control bacterial wilt and increased growth and yields of chili. Those were Bacillus subtilis BSn5,q Bacillus sp. RD-AZPVI-03, Bacillus sp. Y81-1, B.cereus strain C38/15, B.cereus strain APSB-03, and B. subtilis strain CIFT-MFB-4158A. This research aimed to characterize the mechanism of selected Bacillus spp. as biocontrol agents of $R$. solanacearum and as biofertilizer of chili in vitro. We have observed the biocontrol characters (production of HCN, siderophore, biosurfactant, protease, root colonization, and antibiotic), and biofertilizer's characters (production of Indole Acetic Acid (IAA), ammonia and phosphate solubilization) of Bacillus spp. All strains had ability to produce variable concentrations of IAA, B.subtilis strain CIFT-MFB-4158A can produce siderophore, all isolates cannot produce HCN and biosurfactant, 4 isolates can produce protease. Based on the ability to colonize roots, B.subtilis strain CIFT-MFB-4158A had the best ability to colonize root surface $\left(4.17 \times 10^{5} \mathrm{CFU} / \mathrm{g}\right.$ root), while $B$. subtilis $\mathrm{BSn} 5$ had the best ability to colonize internal roots $(2.08 \mathrm{x}$ $\left.10^{5} \mathrm{CFU} / \mathrm{g}\right)$, and 2 Bacillus strains can suppress $R$. solanacearum in vitro.
\end{abstract}

Keywords: Bacillus, in vitro, Indole Acetic Acid, siderophore, protease

Abbreviations: $\mathrm{IAA}=$ Indole Acetic Acid, IRB $=$ Indigenous Rhizobacteria, $\mathrm{ISR}=$ Induce systemic resistance, $\mathrm{NA}=\mathrm{Nutrient}$ agar, PGPR = Plant Growth Promoting Rhizobacteria, $\mathrm{R}=$ Ralstonia, $\mathrm{B}=$ Bacillus

\section{INTRODUCTION}

Ralstonia solanacearum, the causal agent of bacterial wilt disease, is one of the important serious vascular diseases of chili crop which cause losses between $15 \%$ to 55\% around the world (Basu 2014; El-Argawy and Adss 2016). Control is difficult due to high variability of the pathogen, limited possibility for chemical control, high capacity of the pathogen to survive in diverse environments and its extremely wide host range. Controls using biological agents are more desirable because of the availability of variable results from another methods (Nguyen and Ranamukhaarachchi 2010). Since biological control is a key component of integrated disease management, it is important to search for plant growth promoting rhizobacteria (PGPR) active against specific pathogens and evaluates the antagonists for wider application (Nakkeeran et al. 2006).

Between the species of PGPR, Bacillus spp. is wellknown as powerful genera. Several Bacillus species known to promote the health and control diseases by plant pathogens suppressions or by nutrients competitions like iron and phosphate or indirectly fixing nitrogen (McSpaden Gardener 2004). Many Bacillus has the ability to serve as biofertilizers and biopesticides but they are not recognized as pathogenic which makes them easier to handle. Bacillus spp. has ability to move freely, and a good competence on rhizosphere and facultative anaerobes, and those adds its survival ability in soil at various environmental conditions. These bacteria can sporulate in unfavorable conditions and make them more resistant to harsh conditions. This ability is very useful for commercial applications because it will provide long shelf life (Niazi et al. 2014). Bacillus-based biocontrol agents are quite important to control bacterial plant pathogens, such as Pseudomonas syringae on Arabidopsis (Bais et al. 2004), Xanthomonas campestris pv. campestris on Brassica (Wulff et al. 2002), $X$. axonopodis pv. glycines on soybean (Salerno and Sagardoy 2003), Xanthomonas euvesicatoria and Xanthomonas perforans on tomato (Roberts et al. 2008), Ralstonia solanacearum on mulberry ( $\mathrm{Ji}$ et al. 2008) tobacco (Maketon et al. 2008) and chili (Yanti et al. 2017).

Our previous research, based from in planta technique we have found six selected isolates of Bacillus spp. to control $R$. solanacearum and increase growth rate of chili plants (Yanti et al. 2017). From previous 16S rRNA sequencing and identification using BLAST with genebank (http://ncbi.nlih.gov), all six isolates were identified that RZ.2.1.AP3 as Bacillus subtilis BSn5, RZ.2.1.AP1 as Bacillus sp. RD-AZPVI-03, RZ.2.2.AG2 as Bacillus sp. Y81-1, RZ.2.1.AG.1 as Bacillus cereus strain C38/15, 
RZ.1.2.AP1 as Bacillus cereus strain APSB-03, and RZ.1.1.AP1 as Bacillus subtilis strain CIFT MFB 4158A (Yanti et al. 2017 unpublished). In this research, we want to characterize in vitro the selected Bacillus spp. as biocontrol agents of $R$. solanacearum (production of HCN, siderophore, biosurfactant, antibiotic) and as biofertilizer (production of Indole Acetic Acid (IAA), ammonia, protease, phosphate solubilization) and in planta (root colonization).

\section{MATERIALS AND METHODS}

\section{Study area}

This research has been done as an experiment at Laboratory of Microbiology, Department of Plant Protection, and greenhouse, Faculty of Agriculture, University of Andalas, Padang, Indonesia from April to August 2016.

\section{Bacterial strains and culture conditions}

Pathogenic bacteria $R$. solanacearum and six-selected Bacillus spp. (Table 1) from our culture collections in 1.5 $\mathrm{mL}$ microtube contain sterilized aquadest stored in room temperature $\left(27^{\circ} \mathrm{C}\right)$ were used for this study (Yanti et al. 2017). All Bacillus isolates were streaked on Nutrient Agar (NA) (Hymedia ${ }^{\circledR}$ composition per litre, peptone $5 \mathrm{~g}, \mathrm{NaCl}$, $5 \mathrm{~g}$, beef extract $1.5 \mathrm{~g}$, yeast extract $1.5 \mathrm{~g}$, agar $15 \mathrm{~g}, \mathrm{pH} 7.4+$ 0.2 ) culture medium and incubated at room temperature for 48 h. $R$. solanacearum isolate was streaked on Tetrazolium Triphenyl Tetrachloride (TZC) culture medium (composition per litre dextrose $10 \mathrm{~g}$, peptone $10 \mathrm{~g}$, casamino acid $1 \mathrm{~g}$, agar $18 \mathrm{~g}$, TZC $0.005 \%$ ) and incubated with the same methods. These inoculants were prepared in order for them to be used in vitro tests of the Bacillus isolates and also their colonization on chili roots in planta.

\section{In vitro characterization of selected Bacillus spp. mechanisms \\ Biological agents}

Hydrogen cyanide production. Cyanide (HCN) production was determined with cyanide detection agar containing TSA (Hymedia ${ }^{\circledR}$ ) amended with $0.44 \%$ of glycine and detected using $1 \mathrm{~cm}^{2}$ of filter paper dipped in CDS solutions ( $2 \mathrm{~g}$ picric acid, $8 \mathrm{~g}$ of $\mathrm{Na} 2 \mathrm{CO} 3$ in $200 \mathrm{~mL}$ of aquadest) based on method of Lorck (1948). Color shifting from yellow to brownish orange on filter paper was sign of $\mathrm{HCN}$ productions.

Siderophore production. Siderophore production was determined with a method by putting spotted strains into the center of a Chrome Azurol S agar ((compositions are $60.5 \mathrm{mg}$ of Chrome azurol $\mathrm{S}$ dissolved in $50 \mathrm{~mL}$ of aquadest, and mixed with $10 \mathrm{~mL}$ of $\mathrm{FeCl} 3.6 \mathrm{H} 2 \mathrm{O}$ solutions $(1 \mathrm{mM}$ of $\mathrm{FeCl} 3.6 \mathrm{H} 2 \mathrm{O}+10 \mathrm{mM}$ of $\mathrm{HCl})$ then added by $72.9 \mathrm{mg}$ of HDTMA dissolved in $40 \mathrm{~mL}$ of aquadest, the solutions then was added to $900 \mathrm{~mL}$ King's B agar (Hymedia ${ }^{\circledR}$, per litre contains of protease peptone $20 \mathrm{~g}$, K2HPO4 $1.5 \mathrm{~g}$, MgSO4 1.5g, agar $15 \mathrm{~g}$, glycerol $10 \mathrm{~mL} \mathrm{pH} 7.2)$ ) and incubated at $28^{\circ} \mathrm{C}$ for 5 days. The medium color shifting from blue to orange was a sign of siderophore activity (Alexander and Zuberer 1991).
Table 1. List of bacterial strains used in this experiment

\begin{tabular}{ll}
\hline $\begin{array}{l}\text { Bacterial } \\
\text { strain }\end{array}$ & Species \\
\hline RZ.2.1.AP3 & Bacillus subtilis BSn5 \\
RZ2.1.AP1 & Bacillus sp. RD-AZPVI-03 \\
RZ2.2.AG2 & Bacillus sp. Y81-1 \\
RZ2.1.AG1 & Bacillus cereus strain C38/15 \\
RZ1.2.AP1 & Bacillus cereus strain APSB-03 \\
RZ1.1.AP1 & Bacillus subtilis strain CIFT MFB 4158A \\
\hline
\end{tabular}

Hemolytic assay Hemolytic activity was determined using agar diffusion technique by Monteiro et al. (2005) namely by using Blood Agar (TSA (Hymedia ${ }^{\circledR}$ ) enriched with $5 \%$ of sheep blood $\mathrm{pH}$ of 7.3 ) where halo zone (hemolysis) around the colony observed as hemolytic activity.

Biosurfactant production. Biosurfactant production was assayed using Nutrient Broth (NB) Medium (Hymedia $\AA$, which was per litre contains of peptone $5 \mathrm{~g}$, $\mathrm{NaCl} 5 \mathrm{~g}$, beef extract $1.5 \mathrm{~g}$, yeast extract $1.5 \mathrm{~g} \mathrm{pH} 7.2$ ). Bacillus spp. was cultured in culture bottle containing 20 $\mathrm{mL}$ of $\mathrm{NB}$ and was incubated for $48 \mathrm{~h}$ without shaking. Biofilm formations in the surface of the medium was sign of biosurfactant production.

Production of antibiotic against $R$. solanacearum. $R$. solanacearum suspension $\left(10^{8} \mathrm{CFU} / \mathrm{ml}\right.$ adjusted with McFarland solution scale 8) was spread on NA plates and on three holes of $5 \mathrm{~mm}$ diameter punched into the agar. In these holes, $20 \mu \mathrm{l}$ of the culture filtrate of each Bacillus was added and the plates were incubated at $28^{\circ} \mathrm{C}$ for $48 \mathrm{~h}$. Inhibition of $R$. solanacearum growth with halo clear zone is the indicator.

\section{Biofertilizer}

Indole Acetic Acid (IAA) production. Bacillus spp. was inoculated in Nutrient Broth (HiMedia ${ }^{\circledR}$ ) containing $500 \mathrm{mg} \mathrm{L}^{-1}$ L-tryptophan and incubated for for $48 \mathrm{~h}$ on shaker (110rpm). After incubation, the culture was centrifuged and added by $1 \mathrm{ml}$ of supernatant mixed with $4 \mathrm{ml}$ of salkowsky reagent $(1 \mathrm{ml}$ of $\mathrm{FeCl} 30.5 \mathrm{M}, 50 \mathrm{ml}$ of $\mathrm{HClO} 435 \%$ ), and incubated for 20 minutes in temperature room. IAA Production quantitatively was analyzed with methods used in Patten and Glick (2002) using spectrophotometer (Thermo Spectronic, Merck, SA), absorbance at $535 \mathrm{~nm}$.

Ammonia production. Isolates assayed separately in $1 \%$ peptone was dissolved in sterilized water, Bacillus spp. was inoculated in $10 \mathrm{~mL}$ peptone water and incubated for $48-72 \mathrm{~h}$ at $28 \pm 2{ }^{\circ} \mathrm{C}$. $0.5 \mathrm{~mL}$ of Nessler's reagent (SigmaAldrich ${ }^{\circledR}$ - HgI4K2 $0.09 \mathrm{~m} / \mathrm{L}$ ) was added after incubations and the color change to brown yellow color which was a positive result (Cappuccino and Sherman 1992).

Phosphate solubilization. The isolates' ability to solubilize tri-calcium phosphate was assayed using methods of Wahyudi et al. (2011). The isolates was inoculated to Pikovskaya's Agar (Compositons per litre glucose 10g, Ca3 (PO4)2 5g, (NH4)2SO4 0.5g, KCl 0.2g, 
MgSO4.7H2O 0.1g, MnSO4.H2O 0.01g, Yeast extract $0.5 \mathrm{~g}, \mathrm{FeCl} 3.6 \mathrm{H} 2 \mathrm{O} 0.01 \mathrm{~g}$, Agar $15 \mathrm{~g}, \mathrm{pH} 7$ ) separately and was incubated at room temperature for five days with formation of halo indicating positive results.

Protease activity. Protease activity was assayed on Luria Bertani Broth medium (compositions per litre contains Casein enzymic hydrolysate $10 \mathrm{~g}$, Yeast extract $5 \mathrm{~g}$, $\mathrm{NaCl} 10 \mathrm{~g}, \mathrm{pH} 7.5$ (HiMedia ${ }^{\circledR}$ )), and was amended with $2 \%$ of skim milk powder (Nestle) and $15 \mathrm{~g}$ of agar based on methods of Bakker and Schippers (1987). Clearing zones appear around isolates expressed activity of protease.

\section{Root colonization of rifampicin-resistant (Rif) mutants of selected Bacillus}

Root colonization ability of Bacillus strains was assayed with firstly mutated strains accompanied with Rifampicin which was gradually streaked on TSA (Himedia ${ }^{\circledR}$ ) (compositions Tryptone $15 \mathrm{~g} / \mathrm{L}$, soya peptone $5 \mathrm{~g} / \mathrm{L}, \mathrm{NaCl} 5 \mathrm{~g} / \mathrm{L}$ and agar $15 \mathrm{~g} / \mathrm{L}$ ) with concentration of 0 , $10,20,50$ and $100 \mathrm{ppm}$ rifampicin each for 24-36 h. Culture streaked on the last concentration (100ppm) was used for assaying Chili seedlings and then was dipped into mutated Bacillus spp. $\left(10^{6} \mathrm{CFU} / \mathrm{mL}\right)$ for $5 \mathrm{~min}$ and was planted in sterilized soil. Roots of chili then were harvested after 9 days. Bacillus spp. then was re-isolated from external root (rhizospheric) with dipping methods to $10 \mathrm{~mL}$ of sterilized aquadest and vortexed for 2 minutes, and from internal root (endophytic), first, the surface was sterilized sequentially for 1 minute with aquadest, for 1 minutes with $\mathrm{NaOCl} 1 \%$, and for 3 times 1 minutes with aquadest, then was macerated and both (external and internal suspension) was diluted to $10^{-4} .0 .1 \mathrm{~mL}$ of each was homogenized with TSA (when medium was still in liquid state before pouring, and temperature was $45-50^{\circ} \mathrm{C}$ ) containing $100 \mathrm{ppm}$ rifampicin and was plated to petri dishes for $48 \mathrm{~h}$. Colonies growth with the same morphologies then counted.

\section{RESULTS AND DISCUSSION}

\section{Biocontrol mechanism}

In vitro production of $\mathrm{HCN}$ by the six-selected Bacillus spp. was carried out using the picric acid assay. None of these isolates produced HCN (Table 1). Siderophores provide a competitive advantage to organism producer over plant pathogens for the absorption of available iron. Only B. subtilis CIFT MFB 4158A produced siderophore on CAS agar medium. while the others were negative. The hemolytic activity showed by lipopeptides can be used for selecting lipopeptide-producing microorganisms. Therefore, hemolytic activity tests were performed to investigate the possible roleof these compounds in the antimicrobial activity of the Bacillus isolates. None of these isolates showed hemolytic activity. None of these isolates produced biosurfactant. In agar well diffusion assays for antibacterial activity, two Bacillus strains inhibited the growth of $R$. solanacearum, namely $B$. cereus C38/15 and B. subtilis CIFT-MFB-4158A.

\section{Biofertilizer}

Production of IAA by all the selected Bacillus isolates was detected by the production of pink color by all of them. All the Bacillus isolates produced indole acetic acid when grown in media containing tryptophan and it is obvious by the production of pink color by all isolates (Table 2). Using spectrophotometer (Thermo Spectronic, Merck, SA), absorbance at $535 \mathrm{~nm}$ revealed that Bacillus subtilis BSn5 had the highest IAA production (29.25 ppm) while Bacillus subtilis CIFT-MFB-4158A had the lowest IAA production (8.3 ppm). Bacterial isolates were tested for the production of ammonia in peptone water. A total five selected Bacillus isolates produced ammonia and only Bacillus sp. Y81-1 did not produce ammonia. Qualitatively phosphate solubilization was detected on Pikovskaya agar plate, indicated by halo around the inoculated spot. Only Bacillus subtilis CIFT-MFB-4158A showed positive results. All the others were negative without any clear zones. In the study of protease detection, it was found that four-selected Bacillus spp. secreted protease.

\section{Root colonization}

All selected Bacillus spp. have colonized the chili's rhizosphere until 21 days after introduction or after planting, but their population densities have fluctuated from $1.1 \times 10^{4}$ to $8.48 \times 10^{5} \mathrm{cfu} \mathrm{g}^{-1}$ (Figure 1). All Bacillus spp. had ability to colonize and have a good persistence in both rhizospheres and endophytic root.

Colonization of external and internal roots of chili by Bacillus spp. shown various amounts (Figure 1 and 2). All strains showed its ability to colonize both on external and internal (endophyte) of chili seedlings roots. All strains shown decreasing trends based on days after introduction. Although, some strains still showed an increase of populations from time to time, which shown its ability to maintain its populations, others showed inversely.

\section{Discussion}

Our previous study has demonstrated that six-selected Bacillus spp. controlled $100 \%$ of $R$. solanacearum on chili with no Wilt symptom and improved the growth of $R$. solanacearum-inoculated chili plants (Yanti et al. 2017). These may have been happened by direct antagonism of pathogens, production of antibiotic, or competition with pathogens for nutrients (Gamliel and Katan 1993). The present study demonstrates that biocontrol characters of the selected Bacillus spp. were presented in Table 1. As shown in Table 1, only B. subtilis CIFT-MFB-4158A produced siderophore and antibiotic for growth inhibition of $R$. solanacearum. The other Bacillus spp. which also produced antibiotic was Bacillus cereus C38/15. All selected Bacillus spp. showed negative for the other characters, such as: HCN, siderophore, hemolytic activity and biosurfactant. This study showed that direct mechanism's characters of Bacillus spp. have not played an important role to control $R$. solanacearum on chili. 
Table 1. Characters of selected Bacillus spp. as a biocontrol agent.

\begin{tabular}{|c|c|c|c|c|c|c|}
\hline \multirow[b]{2}{*}{$\begin{array}{c}\text { Bacterial } \\
\text { strains }\end{array}$} & \multirow[b]{2}{*}{ Bacillus species } & \multicolumn{5}{|c|}{ Characteristics as biocontrol agent } \\
\hline & & $\begin{array}{c}\text { HCN } \\
\text { production }\end{array}$ & $\begin{array}{c}\text { Siderophore } \\
\text { production }\end{array}$ & $\begin{array}{c}\text { Hemolytic } \\
\text { activity }\end{array}$ & $\begin{array}{c}\text { Biosurfactant } \\
\text { production }\end{array}$ & $\begin{array}{l}\text { Antibiotic } \\
\text { production }\end{array}$ \\
\hline RZ2.1.AP3 & Bacillus subtilis BSn5 & - & - & - & - & - \\
\hline RZ2.1.AP1 & Bacillus sp. RD-AZPVI-03 & - & - & - & - & - \\
\hline RZ2.2.AG2 & Bacillus sp. Y81-1 & - & - & - & - & - \\
\hline RZ2.1.AG1 & Bacillus cereus $\mathrm{C} 38 / 15$ & - & - & - & - & + \\
\hline RZ1.2.AP1 & Bacillus cereus APSB-03 & - & - & - & - & - \\
\hline RZ1.1.AP1 & Bacillus subtilis CIFT MFB 4158A & - & + & - & - & + \\
\hline
\end{tabular}

Table 2. Characters of selected Bacillus spp. as biofertilizer

\begin{tabular}{|c|c|c|c|c|c|}
\hline \multirow{2}{*}{$\begin{array}{l}\text { Bacterial } \\
\text { strains }\end{array}$} & \multirow[t]{2}{*}{ Bacillus species } & \multicolumn{4}{|c|}{ Characteristics as biofertilizer } \\
\hline & & $\begin{array}{l}\text { IAA Production } \\
(\mathrm{ppm})\end{array}$ & $\begin{array}{c}\text { Ammonia } \\
\text { production }\end{array}$ & $\begin{array}{c}\text { Phosphate } \\
\text { solubilization }\end{array}$ & $\begin{array}{c}\text { Protease } \\
\text { activity }\end{array}$ \\
\hline RZ2.1.AP3 & Bacillus subtilis BSn5 & 29.25 & + & - & - \\
\hline RZ2.1.AP1 & Bacillus sp. RD-AZPVI-03 & 24.05 & + & - & + \\
\hline RZ2.2.AG2 & Bacillus sp. Y81-1 & 23.05 & - & - & + \\
\hline RZ2.1.AG1 & Bacillus cereus $\mathrm{C} 38 / 15$ & 15.75 & + & - & + \\
\hline RZ1.2.AP1 & Bacillus cereus APSB-03 & 22.05 & + & - & - \\
\hline RZ1.1.AP1 & Bacillus subtilis CIFT-MFB-4158A & 8.30 & + & + & + \\
\hline
\end{tabular}

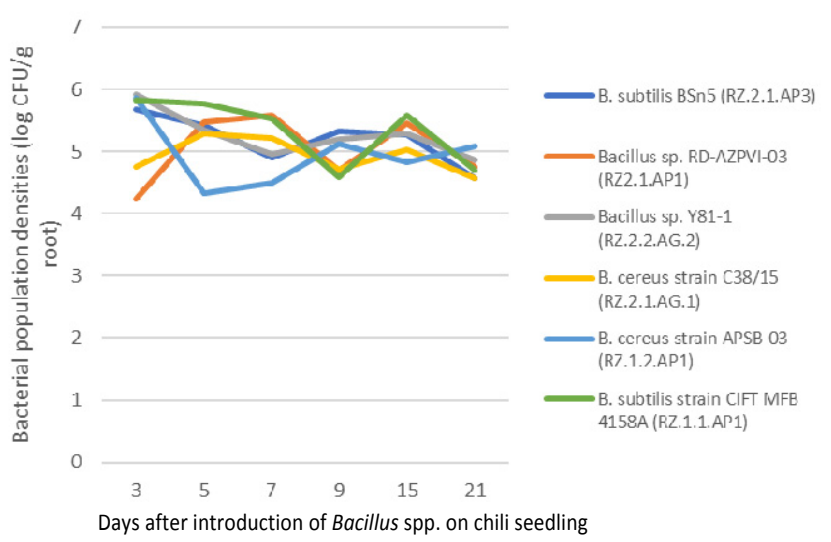

Figure 1. Population densities of selected Bacillus spp. in the rhizospheres of chili at 3 until 21 days after planting (DAP)

The biofertilizer characters of the selected Bacillus spp. were as shown in Table 2. All selected Bacillus spp., could induced IAA productions. The IAA productions of selected Bacillus spp. were varied from 8.30 to $29.25 \mathrm{ppm}$. Bacillus subtilis BSn5 produced higher IAA than the other Bacillus spp.. IAA production by PGPR had been reported to be varied among different species and was influenced by culture condition, growth stage and substrate ability (Mirza et al. 2001; Mishra et al. 2010).

The IAA produced by Bacillus played a major role in roots elongation and could directly promote roots growth by cells elongation and cells division stimulation or could indirectly influence ACC-deaminase activity in rhizobacteria (Rathaur et al. 2012). Patten and Glick (2002)

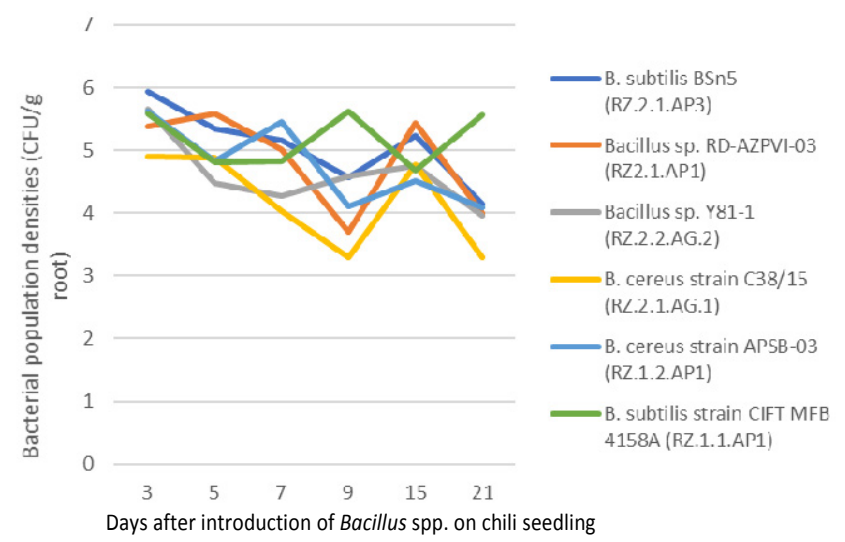

Figure 2. Population densities of Bacillus spp. as an endophyte in the chili root tissue from 3 until 21 days after planting (DAP)

also reported that various IAA concentrations could induce different stimulations to plants. Low levels of IAA could stimulate roots elongation, while high levels of IAA would stimulate the lateral and adventitious roots formation. IAA was part of many secondary metabolites produced by PGPR in abundance during the stationary phase (Wahyudi, et al. 2011). This explained that the ability of B. subtilis CIFT MFB 4158A with low level of IAA production and its combination with phosphate solvent could also increase growth rate. B. amyloliquefaciens strain FZB42 was also found producing IAA and stimulating the growth of plant (Idris et al. 2007).

Bacillus subtilis strain produced a variety of powerful antibiotic metabolites (Peyopux et al. 1999) and 
lipopeptides belonging to surfactin, iturin and fengycin families (Rahman et al. 2002). Hemolysis assay is the sole method widely used to screen biosurfactant production (Yonebayashi et al. 2000). In this study, all strains did not show any ability to produce biosurfactants. However, all strains showed a good ability to colonize roots, and it is showed that there is any other ability that helps the strains to colonize rhizosphere and endophyte of roots. Bacterial endophytes are well known for its beneficial effects for host plants (Puente et al. 2009). The ecological niches that are similar with phytopathogens, makes endophytic bacteria more suitable as biocontrol agents (Berg et al. 2005) and more stable to control pathogens. The growth reductions of $R$. solanacearum by Bacillus spp. and its in vitro inhibition zones are probably due to its ability to produce lytic enzymes like protease and a synthesis of antibiotics, which are most common character associated in PGPR (Mazurier et al. 2009).

Based on the properties of strains, only little direct activities showed relation to biocontrol activity, whereas from previous research (Yanti et al. 2017), all isolates have shown best biocontrol activity with no $R$. solanacearum symptoms appears. Based on these results, it can be concluded that most of all strains' ability in controlling $R$. solanacearum are not via direct mechanisms. According to Kloepper et al. (1999), ISR could be one of the most important mechanisms against systemic pathogens such as $R$. solanacearum. Other studies had reported that ISR can be triggered by inoculation of bacteria (Van Peer et al. 1990; Benhamou et al. 1996; Wilhelm et al. 1998). A further research is needed to be done to characterize all the bacterium activity in inducing systemic resistance of chili plants.

Our research concluded that these Bacillus strains had good traits characters to both promote plant growth and control pathogens. All strains also had ability to colonize internal (endophyte) and rhizosphere of chili roots. These Bacillus strains have potential to be used as biofertilizer and biocontrol agent of bacterial wilt of chili and further research for the commercial production is needed.

\section{ACKNOWLEDGEMENTS}

This research was funded by Hibah Guru Besar Universitas Andalas, Padang, West Sumatra, Indonesia, Contract No. 38/UN.16.17/PP.HGBLPPM/2017 March $21^{\text {th }}, 2017$.

\section{REFERENCES}

Alexander DB, Zuberer DA. 1991. Use of chrome azurol S reagents to evaluate siderophore production by rhizosphere bacteria. Biol Fertil Soils 2: 39-45.

Bais HP, Fall R, Vivanco JM. 2004. Biocontrol of Bacillus subtilis against infection of Arabidopsis roots by Pseudomonas syringae is facilitated by biofilm formation and surfactin production. Plant Physiol 134: 307-319.

Bakker AW and Schippers B. 1987. Microbial cyanide production in the rhizosphere in relation to potato yield reduction and Pseudomonas spp. mediated plant growth stimulation. Soil Biol Biochem 19: 451457.

Basu A. 2014. Bio-efficacy of Pseudomonas fluorescens (7\% WP and 5\% SC formulations) against bacterial wilt disease of chili. Asia Pacific J Sustain Agric Food Energ 2 (2): 36-40.

Benhamou N, Kloepper JW, Quadt-Hallmann A, Tuzun S. 1996. Induction of defence-related ultrastructural modifications in pea root tissues inoculated with endophytic bacteria. Plant Physiol 112: 919929.

Berg G, Eberl L, Hartmann A. 2005. The rhizosphere as a reservoir for opportunistic human pathogenic bacteria. Environ Microbiol 7: 16731685

Cappuccino JG, Sherman N. 1992. Microbiology, A Laboratory Manual. Addison Wesley, Reading, MA.

El-Argawy E and Adss I A. 2016. Quantitative gene expression of peroxidase, polyphenoloxidase and catalase as molecular markers for resistance against Ralstonia solanacearum. Amer J Mol Biol 6 (2): 88 .

Gamliel A, Katan J. 1993. Suppression of major and minor pathogens by fluorescent pseudomonads in solarized and non-solarized soil. Phytopathology 83: 68-75.

Idris EE, Iglesias DJ, Talon M, Borriss R. 2007. Tryptophan-dependent production of indole-3-acetic acid (IAA) affects level of plant growth promotion by Bacillus amyloliquefaciens FZB42. Mol. Plant-Microbe Interact 20: 619-626.

Ji XL, Lu GB, Gai YP, Zheng CC, Mu ZM. 2008. Biological control against bacterial wilt and colonization of mulberry by an endophytic Bacillus subtilis strain. FEMS Microbiol Ecol 65 (3): 565-573.

Kloepper JW, Rodriguez-Kabana R, Zehnder GW, Murphy JF, Sikora E, Fernandez C. 1999. Plant root-bacterial interactions in biological control of soilborne diseases and potential extension to systemic and foliar diseases. Australasian Plant Pathol 28: 21-26.

Lorck H. 1948. Production of hydrocyanic acid by bacteria. Physiol Plant 1: $142-146$.

Maketon M, Apisitsantikul J, Siriraweekul C. 2008. Greenhouse evaluation of Bacillus subtilis AP-01 and Trichoderma harzianum AP-001 in controlling tobacco diseases. Braz J Microbiol 39 (2): 296300.

Mazurier S, Corberand T, Lemanceau P, Raaijmakers JM. 2009. Phenazine antibiotics produced by fluorescent pseudomonads contribute to natural soil suppressiveness to Fusarium wilt. ISME J 3 (8): 977-991.

McSpaden Gardener BB. 2004. Ecology of Bacillus and Paenibacillus spp. in agricultural systems. Phytopathology 94: 1252-1258

Mirza MS, Ahmad W, Latif F, Haurat J, Bally R, Normand P, Malik KA. 2001. Isolation, partial characterization and effect of plant growth promoting bacteria on micropropagated sugarcane in vitro. Plant Soil 237: 47-54.

Mishra M, Kumar U, Mishra PK, Prakash V. 2010. Efficiency of plant growth promoting rhizobacteria for the enhancement of Cicer arietinum L. growth and germination under salinity. Adv Biol Res 4 (2): 92-96.

Monteiro L, Mariano RdeLR and Souto-Maior AM. 2005. Antagonism of Bacillus spp. against Xanthomonas campestris pv. campestris. Braz Arch Biol Technol 48 (1): 23-29.

Nakkeeran S, Kavitha K, Chandrasekar G, Renukadevi P, and Fernando WGD. 2006. Induction of plant defence compounds by Pseudomonas chlororaphis PA23 and Bacillus subtilis BSCBE4 in controlling damping-off of hot pepper caused by Pythium aphanidermatum. Biocontr Sci Technol 16 (4): 403-416.

Nguyen MT, Ranamukhaarachchi SL. 2010. Soil-borne antagonists for biological control of bacterial wilt disease caused by Ralstonia solanacearum in tomato and pepper. J Plant Pathol 92 (2): 395-406.

Niazi A, Manzoor S, Asari S, Bejai S, Meijer J, Bongcam-Rudloff E. 2014. Genome analysis of Bacillus amyloliquefaciens subsp. plantarum UCMB5113: a rhizobacterium that improves plant growth and stress management. PLoS One 9 (8) e104651: 1-15. DOI: 10.1371/journal.pone.0104651.

Patten CL, Glick BR. 2002. Role of Pseudomonas putida indolacetic acid in development of the host plant root system. Appl Environ Microbiol 68: 3795-3801.

Peypoux F, Bonmatin JM, Wallach J. 1999. Recent trends in the biochemistry of surfactin. Appl Environ Microbiol 51: 553-563.

Puente ME, Li CY, Bashan Y. 2009. Endophytic bacteria in cacti seeds can improve the development of cactus seedlings. Environ Exp Bot 66: 402-408. 
Rahman KSM, Rahman TJ, McClean S. 2002. Rhamnolipid biosurfactant production by strains of Pseudomonas aeruginosa using low-cost raw materials. Biotechnol Prog 18: 1277-1281

Rathaur P, Ramteke PW, Waseem W, John SA. 2012. Isolation and characterization of nickel and cadmium tolerant plant growth promoting rhizobacteria from rhizosphere of Withania somnifera. J Biol Environ Sci 6: 253-261.

Roberts PD, Momol MT, Ritchie L, Olson SM, Jones JB, Balogh B. 2008 Evaluation of spray programs containing famoxadone plus cymoxanil, acibenzolar-S-methyl, and Bacillus subtilis compared to copper sprays for management of bacterial spot on tomato. Crop Protect 27 (12): $1519-1526$

Salerno CM, Sagardoy MA. 2003. Antagonistic activity by Bacillus subtilis agains Xanthomonas campestris pv. glycines under controlled conditions. Spanish J Agric Res 1: 55-58.

Van Peer R, Kuik AJ, Rattink H, Schippers B. 1990. Control of Fusarium wilt in carnation grown on rockwool by Pseudomonas sp. strain WCS417r and by FeEDDHA Netherlands. J Plant Pathol 96: 119-132.

Wahyudi AT, Astuti RP, Widyawati A, Mery A, Nawangsih AA. 2011. Characterization of Bacillus sp. strains isolated from rhizosphere of soybean plants for their use as potential plant growth for promoting rhizobacteria. J Microbiol Antimicrob 3 (2): 34-40.

Wilhelm E, Arthoefer W, Schafleitner R, Krebs B. 1998. Bacillus subtilis an endophyte of chestnut (Castanea sativa) as antagonist against chestnut blight (Cryphonectria parasitica). Plant Cell Tiss Org Cult 52: $105-108$

Wulff EG, Mguni CM, Mansfeld-Giese K, Fels J, Lübeck M, Hockenhull J. 2002. Biochemical and molecular characterization of Bacillus amyloliquefaciens, B. subtilis and B. pumilus isolates with distinct antagonistic potential against Xanthomonas campestris pv. campestris. Plant Pathol 51 (5): 574-584.

Yanti Y, Astuti FF, Habazar T, Reflinaldon, Nasution CR. 2017. Screening of rhizobacteria from rhizosphere of healthy chili to control bacterial wilt disease and to promote growth and yield of chili. Biodiversitas 18 (1): 1-9.

Yonebayashi H, Yoshida S, Ono K. 2000. Screening of microorganisms for microbial enhanced oil recovery process. Sekiyu Gakkaishi 43: 59-69. 